\title{
ОСОБЛИВОСТІ ЕМОЦІЙНОГО ВИГОРАННЯ ТА ЙОГО РОЛЬ В СТРУКТУРІ ДЕЗАДАПТАЦІЇ ВОЛОНТЕРІВ, ДІЯЛЬНІСТЬ ЯКИХ ПОВ'ЯЗАНА З ЗАБЕЗПЕЧЕННЯМ ВІЙСЬКОВИХ В ЗОНІ АТО
}

\author{
УДК: 159.972:159.922.2:616-092.12:159.913:616-084
}

\begin{abstract}
Маркова Маріанна Владиславівна
Доктор медичних наук, професор, професор кафедри сексології, медичної психологї, медичної $i$ психологічної реабілітачії Харківської медичної академії післядипломної освіти, м. Харків (Украӥна)
\end{abstract}

\section{Глаголич Слава Юрӥвна}

Психолог Закарпатського обласного наркологічного диспансеру, м. Ужсгород (Україна)

\begin{abstract}
Анотація. Метою роботи було вивчення особливостей емочійного вигорання та психологічної дезадаптачії украӥнських волонтерів. За допомогою клініко-психологічного та психодіагностичного методів обстежено 147 осіб, щзо займалися волонтерською діяльністю, пов'язаною з забезпеченням військових в зоні АТО, не менше 1 року. Встановлено, що волонтерська діяльність несе потенційні ризики розвитку синдрому емоційного вигорання (CEB). У 61,2\% з загальної кількості обстежених осіб, встановлено наявність або окремих фаз СЕВ, щуо формуються (34,0\%), або сформованих (27,2\%). Поява ознак СЕВ передує появі клінічно окреслених дезадаптивних проявів та впливає на їх структуру. СЕВ, вмикаючи механізми захисту від стресу, підвищує прояви дезадаптації щуодо волонтерської діяльності, щзо в сукупності негативно впливає на фізичне, психологічне та соціальне функціонування волонтерів.
\end{abstract}

Ключові слова: волонтери, АТО, дезадаптація, емоційне вигорання.

\section{Постановка проблеми у загальному}

вигляді. 3 початком на сході України воєнних подій та антитерористичної операції (АТО), кількість волонтерів та волонтерських організацій, які надавали та надають допомогу українській армії, значно зросла [1].
Волонтерська діяльність включає додаткові елементи ризику, пов'язані із особливостями контакту з людськими стражданнями i втратами. Цей ризик значно зростає у кризові періоди життя суспільства, коли кількість людей, що потребують допомоги, суттєво збіль- 
шується [2].

В умовах збройного конфлікту, волонтерська діяльність в Україні характеризується значним фізичним, психологічним та емоційним навантаженням, суттєвою зміною ритму життя, а подекуди, й ризиком для життя. Серед негативних медико-психологічних наслідків, за таких умов, найбільш значущим стає високий ризик «професійного вигорання» волонтерів.

Окрім додаткових особистісних викликів, волонтери відмічають негативний вплив зовнішніх факторів: «Найбільше вигораєш, коли зустрічаєшся 3 байдужістю, коли чуєш від людей: «Це не моя війна». Багато волонтерів чесно і відкрито кажуть: був момент, коли було важко та потрібна була наша допомога, але пора вже державі зайняти своє місце, повинні запрацювати державні механізми. Адже, волонтери беруть кошти із кишень людей, які, щоб допомогти армії, економлять на відпочинку, освіті, розвитку, на деяких банальних речах. I при цьому ще й податки платять, на які, власне, має утримуватись армія» [3].

«Навіть найстійкіші українці - волонтери - на третій рік війни зізнаються, що в них уже зовсім нема сили і навіть жити не хочеться. Після трагічної загибелі волонтера Юрія Мосіна, який покінчив життя самогубством, зневірившись у тому, що може повернутися до нормального життя, соціальними мережами прокотилася низка одкровень, чимось схожих на акцію «\#янебоюсьсказати». Волон- тери зізнавалися, що знесилені. Що змучені і не відчувають більше наснаги допомагати. I відчувають через себе винними. І вже без оптимізму дивляться у завтрашній день» [4].

На теперішній час актуальним є тренд зниження кількості осіб, які займаються волонтерством: із 26\% в 2014 до 13\% в 2015 році, що відображене у світовому рейтингу благодійності, який формується британською організацією Charity Aid Foundation [5].

Повідомлення про накопичення втоми та спад волонтерської активності все більше і все частіше з'являються в засобах масової інформації та ширяться соціальними мережами [6-11].

Волонтери описують власний стан, як надмірну втому, аж до виснаження, появу проблем із здоров'ям, зневіру, втрату ідеалізму та захоплення тим, що роблять аж до розчарування [12; 15].

Емоційне вигорання - особлива форма професійної дезадаптації людини, що призводить до зниження якості роботи, втрати інтересу до неї і навіть до зміни роду діяльності. Воно $є$ причиною порушень фізичного і психічного здоров'я. Даний психологічний конструкт включає в себе тривалу відповідь на стрес-фактори, пов'язані із діяльністю.

Визначення ВООЗ трактує даний синдром як стрес-реакцію на трудове та емоційне навантаження, пов'язане з бурхливим темпом життя, трудових та суспільних відносин.

На думку спеціалістів ВООЗ, синдро- 
мемоційного вигорання визнається проблемою, яка потребує спеціалізованої допомоги та в зв'язку з цим внесена в лексикони психіатрії (ВОО3), згідно яких емоційне вигорання це фізичне, емоційне i/або мотиваційне виснаження, що характеризується порушенням продуктивності в роботі та втомою, безсонням, підвищеною схильністю до соматичних захворювань, а також вживанням алкоголю або інших психоактивних речовин 3 метою одержати тимчасове полегшення, що має тенденцію до розвитку фізіологічної залежності та (в багатьох випадках) суїцидальної поведінки [16].

За Міжнародною класифікацією хвороб $\mathrm{X}$ перегляду, цей стан належить до рубрики Z 73 «Стрес, пов'язаний з труднощами підтримки нормального способу життя» [17].

В зв'язку з цим, гостро стає проблема вивчення синдрому емоційного вигорання, як складової психологічної дезадаптації волонтерів.

\section{Аналіз останніх досліджень i} публікацій. За останні десятиліття 3'явилась велика кількість досліджень, присвячених вивченню особливостей синдрому емоційного вигорання (CEB), особливо в комунікативних видах діяльності [18-22], оскільки він має безпосереднє відношення до збереження здоров'я осіб, включених в тривалі міжособистісні комунікації. Однак, як показав аналіз наявних досліджень та наукових публікацій, такий аспект проблеми, як оцінка проявів СЕВ та його роль в структурі дезадаптації волонтерів, не вирішений в науково-теоретичному плані, i потребує подальшої розробки.

В існуючих умовах, враховуючи кількість залучених до волонтерства громадян України та невизначеність термінів тривання гострої кризової ситуації в країні, проблема емоційного вигорання волонтерів та їх дезадаптації $є$ однією з найвагоміших і набуває особливої актуальності.

Таким чином, актуальність дослідження визначається високою ймовірністю виникнення у волонтерів емоційного вигорання під впливом складних умов реалізації волонтерської діяльності в умовах АТО, недостатньою вивченістю проблеми «вигорання» у волонтерів, відсутністю надійних та апробованих методик профілактики та корекції явища емоційного вигорання у волонтерів.

Метою роботи було оцінка проявів CEB та визначення його ролі в структурі дезадаптації волонтерів, $з$ метою встановлення мішеней їх медико-психологічної підтримки та розробки рекомендацій по його попередженню та корекції.

\section{Контингент і методи дослідження.}

Всього було обстежено 147 осіб, що займалися волонтерською діяльністю, пов'язаною 3 забезпеченням військових в зоні АТО, не менше 1 року. Серед обстежених превалювали жінки - 108 осіб (73,5\% від загальної кількості), середній вік - 28,02 $\pm 4,33$; чоловіків - 39 (26,5\%), середній вік $-30,79 \pm 4,57$ років.

Оцінку рівня та основних клініко- 
соціальних особливостей дезадаптації було проведено за допомогою опитувальника «Оцінка професійної дезадаптації (ПД)» О. Н. Родіної в адаптації М. А. Дмитрієвої. Даний опитувальник дозволяє визначити порушення рівноваги між людиною та професійним середовищем, виникнення дезадаптивних станів та їх варіативну ступінь вираженості: від легких порушень у встановленні рівноваги 3 професійним середовищем до станів, при виникненні яких необхідне втручання спеціалістів 3 метою зниження негативного ефекту [23].

Для найбільш комплексної та детальної лактики та психокорекції [24].

Результати дослідження та їх обгово-

рення. За рівнем вираженості ПД серед обстежених було виділено дві групи:

- перша група (Г1) - 104 особи (70,7 \% від загальної кількості), група умовної норми, у представників якої виявлені незначні порушення, що не досягали клінічного рівня;

- друга група (Г2) - 43 особи (29,3 \% від загальної кількості), 3 наявними явищами або ознаками дезадаптації.

Попередня оцінка ознак СЕВ в досліджуваних групах дозволила визначити їх частоту та рівень сформованості (Табл. 1).

Таблиия 1.

\section{Частота та рівень сформованості СЕВ за фазами}

\begin{tabular}{|l|c|c|c|c|c|c|c|}
\hline \multirow{2}{*}{ Сформованість СЕВ } & \multicolumn{2}{|c|}{$\Gamma 1$} & \multicolumn{2}{c|}{$\Gamma 2$} & \multicolumn{2}{c|}{ Всього } & \multirow{2}{*}{$\mathrm{p}$} \\
\cline { 2 - 9 } & абс. & $\%$ & абс. & $\%$ & абс. & $\%$ & \\
\hline Не сформовано жодну з фаз СЕВ & 57 & 54,8 & 0 & 0,0 & 57 & 38,8 & $<0,01$ \\
\hline $\begin{array}{l}\text { Формується щонайменше одна 3 } \\
\text { фаз СЕВ }\end{array}$ & 47 & 45,2 & 3 & 7,0 & 50 & 34,0 & $<0,01$ \\
\hline $\begin{array}{l}\text { Сформовано щонайменше одну } 3 \\
\text { фаз СЕВ }\end{array}$ & 0 & 0,0 & 40 & 93,0 & 40 & 27,2 & $<0,01$ \\
\hline Всього & 104 & 100,0 & 43 & 100,0 & 147 & 100,0 & - \\
\hline
\end{tabular}

діагностики, дослідження синдрому емоційного вигорання, як складової дезадаптації, проводилось за допомогою методики «Діагностика рівня «емоційного вигорання»»» В. В. Бойка. Ця методика дозволяє діагностувати емоційне вигорання на різних стадіях його протікання, дає детальну картину синдрому «емоційного вигорання» та достатньо об'ємну характеристику особистості, а також дозволяє намітити індивідуальні міри профі-
В загальній групі респондентів (n=147), тільки у 57 осіб $(38,8 \%)$ Г1, без клінічно окреслених ознак дезадаптації, не встановлено жодної з фаз СЕВ, що формується чи сформована.

У 90 осіб (61,2\%), встановлено наявність окремих фаз СЕВ, що формуються (34,0\%) або сформовані (27,2\%), що підтверджує необхідність детального вивчення структури, особливостей СЕВ, його роль у виник- 
ненні та формуванні ознак дезадаптації та факторів, що впливають на формування СЕВ у волонтерів для розробки адекватних до встановлених порушень засобів профілактики та корекції.

I3 них, в Г1 встановлено формування CEB за окремими фазами у 47 осіб (32\%); в Г2 - у 3 осіб (2\%); сформований СЕВ встановлено у 40 осіб $(27,2 \%)$ Г2.

Аналіз особливостей вираженості окремих симптомів CEB за даними опитувальника В. В. Бойка дозволив встановити низькі показники у волонтерів з ознаками ПД за всіма фак- торами (фазами) та симптомами (шкалами), що входять до їх складу, за винятком емоційно-моральної дезорієнтації (Табл. 2).

Як видно 3 таблиці, у обстежених Г1 середні значення за усіма симптомами СEB, крім симптому «Резистенція. Розширення сфери економії емоцій», відповідають рівню не сформованих (менше 9 балів), тоді як у Г2 середнє значення $є$ меншими за цей рівень лише для одного симптому («Резистенція. Емоційно-моральна дезорієнтація»). Вираженість ще чотирьох симптомів («Напруга. Незадоволеність собою», «Резистенція. Неадекватне емо-

Таблиия 2.

\section{Вираженість СЕВ (за симптомами та фазами) у обстежених основної групи (Г2) та групи порівняння (Г1) (середній бал)}

\begin{tabular}{|c|c|c|c|c|}
\hline \multirow{2}{*}{ Фаза / Симптом } & \multicolumn{3}{|c|}{ Середнє значення, $\mathrm{M} \pm \mathrm{m}$ (балів) } & \multirow{2}{*}{$\mathrm{p} \Gamma 1 / \Gamma^{2}$} \\
\hline & $\Gamma 1$ & $\Gamma 2$ & Разом & \\
\hline $\begin{array}{l}\text { 1.1. Напруга. Переживання психотравмуючих об- } \\
\text { ставин }\end{array}$ & $3,21 \pm 4,75$ & $22,63 \pm 6,58$ & $8,89 \pm 10,34$ & $<0,01$ \\
\hline 1.2. Напруга. Незадоволеність собою & $5,11 \pm 3,26$ & $14,28 \pm 2,90$ & $7,79 \pm 5,24$ & $<0,01$ \\
\hline 1.3. Напруга. Загнаність у клітку & $1,42 \pm 2,46$ & $16,14 \pm 4,89$ & $5,73 \pm 7,50$ & $<0,01$ \\
\hline 1.4. Напруга. Тривога і депресія & $4,07 \pm 3,42$ & $21,28 \pm 5,49$ & $9,10 \pm 8,87$ & $<0,01$ \\
\hline Напруга & $13,81 \pm 7,74$ & $74,33 \pm 9,70$ & $31,51 \pm 28,85$ & $<0,01$ \\
\hline $\begin{array}{l}\text { 2.1. Резистенція. Неадекватне емоційне вибіркове } \\
\text { реагування }\end{array}$ & $3,38 \pm 3,92$ & $14,30 \pm 5,97$ & $6,57 \pm 6,78$ & $<0,01$ \\
\hline $\begin{array}{l}\text { 2.2. Резистенція. Емоційно-моральна дезорієнта- } \\
\text { ція }\end{array}$ & $7,68 \pm 4,66$ & $7,58 \pm 5,39$ & $7,65 \pm 4,87$ & $>0,05$ \\
\hline $\begin{array}{l}\text { 2.3. Резистенція. Розширення сфери економії емо- } \\
\text { цій }\end{array}$ & $14,23 \pm 11,64$ & $22,91 \pm 8,29$ & $16,77 \pm 11,45$ & $<0,01$ \\
\hline 2.4. Резистенція. Редукція професійних обов'язків & $6,38 \pm 6,70$ & $15,07 \pm 1,68$ & $8,92 \pm 6,94$ & $<0,01$ \\
\hline Резистенція & $31,66 \pm 12,25$ & $59,86 \pm 10,63$ & $39,91 \pm 17,44$ & $<0,01$ \\
\hline 3.1. Виснаження. Емоційний дефіцит & $4,25 \pm 4,07$ & $9,84 \pm 5,67$ & $5,88 \pm 5,24$ & $<0,01$ \\
\hline 3.2. Виснаження. Емоційна відстороненість & $8,70 \pm 3,27$ & $14,30 \pm 3,02$ & $10,34 \pm 4,09$ & $<0,01$ \\
\hline $\begin{array}{l}\text { 3.3. Виснаження. Особистісна відстороненість } \\
\text { (деперсоналізація) }\end{array}$ & $4,35 \pm 4,64$ & $19,60 \pm 4,40$ & $8,81 \pm 8,32$ & $<0,01$ \\
\hline $\begin{array}{l}\text { 3.4. Виснаження. Психосоматичні і психовегета- } \\
\text { тивні порушення) }\end{array}$ & $3,02 \pm 2,74$ & $19,42 \pm 5,10$ & $7,82 \pm 8,30$ & $<0,01$ \\
\hline Виснаження & $20,32 \pm 9,96$ & $63,16 \pm 11,13$ & $32,85 \pm 22,10$ & $<0,01$ \\
\hline Всього & $65,79 \pm 22,98$ & $197,35 \pm 23,67$ & $104,27 \pm 64,35$ & $<0,01$ \\
\hline
\end{tabular}


ційне вибіркове реагування», «Резистенція. Редукція професійних обов'язків», «Виснаження. Емоційна відстороненість» та «Виснаження. Емоційний дефіцит») відповідає рівню симптому, що складається (до 16 балів), а показники за рештою шкал відповідають рівню симптому, що склався (понад 16 балів).
Залежно від рівня дезадаптації та вираженості СЕВ за середнім балом нами були виділені наступні групи: Г1-0 (n=57) - явища дезадаптації та прояви СЕВ відсутні; Г1-1 $(\mathrm{n}=47)$ та Г2-1(n=3) - наявні окремі ознаки дезадаптації та окремі фази СЕВ, що формуються; Г2-2(n=40) - наявні явища дезадаптації та сформовані фази СЕВ (Табл. 3).

Таблиия 3.

\section{Вираженість СЕВ (за симптомами та фазами) у обстежених за групами СЕВ (середній бал)}

\begin{tabular}{|c|c|c|c|c|c|c|c|c|c|c|}
\hline \multirow[b]{2}{*}{ Фаза / Симптом } & \multicolumn{4}{|c|}{ Середнє значення, $\mathrm{M} \pm \mathrm{m}$ (балів) } & \multicolumn{6}{|c|}{ Розбіжності } \\
\hline & $\Gamma 1-0$ & $\Gamma 1-1$ & $\Gamma 2-1$ & $\Gamma 2-2$ & $\begin{array}{c}\mathrm{p} \text { Г1- } \\
0 / \Gamma 1-1\end{array}$ & $\begin{array}{l}\mathrm{p} \Gamma 1- \\
0 / \Gamma 1-2\end{array}$ & $\begin{array}{l}\mathrm{p} \Gamma 1- \\
0 / \Gamma 2-2\end{array}$ & $\begin{array}{l}\mathrm{p} \Gamma 1- \\
1 / \Gamma 2-1\end{array}$ & $\begin{array}{l}\mathrm{p} \Gamma 1- \\
1 / \Gamma 2-2\end{array}$ & $\begin{array}{l}\mathrm{p} \text { Г2- } \\
1 / \Gamma 2- \\
2\end{array}$ \\
\hline $\begin{array}{l}\text { 1.1. Напруга. Пережи- } \\
\text { вання психотравмуючих } \\
\text { обставин }\end{array}$ & $1,96 \pm 0,26$ & $4,72 \pm 6,80$ & $14,67 \pm 5,77$ & $23,23 \pm 6,29$ & $<0,05$ & $<0,01$ & $<0,01$ & $<0,05$ & $<0,01$ & $>0,05$ \\
\hline $\begin{array}{l}\text { 1.2. Напруга. Незадово- } \\
\text { леність собою }\end{array}$ & $3,23 \pm 2,65$ & $7,38 \pm 2,37$ & $15,33 \pm 2,52$ & $14,20 \pm 2,94$ & $<0,01$ & $<0,01$ & $<0,01$ & $<0,01$ & $<0,01$ & $>0,05$ \\
\hline $\begin{array}{l}\text { 1.3. Напруга. Загнаність } \\
\text { у клітку }\end{array}$ & $1,40 \pm 1,70$ & $1,45 \pm 3,16$ & $13,00 \pm 5,29$ & $16,38 \pm 4,85$ & $>0,05$ & $<0,01$ & $<0,01$ & $<0,01$ & $<0,01$ & $>0,05$ \\
\hline $\begin{array}{l}\text { 1.4. Напруга. Тривога i } \\
\text { депресія }\end{array}$ & $3,68 \pm 2,31$ & $4,53 \pm 4,40$ & $12,67 \pm 2,89$ & $21,93 \pm 5,09$ & $>0,05$ & $<0,01$ & $<0,01$ & $<0,05$ & $<0,01$ & $<0,05$ \\
\hline Напруга & $10,28 \pm 3,93$ & $18,09 \pm 9,02$ & $55,67 \pm 7,23$ & $75,73 \pm 8,36$ & $<0,01$ & $<0,01$ & $<0,01$ & $<0,01$ & $<0,01$ & $<0,01$ \\
\hline $\begin{array}{l}\text { 2.1. Резистенція. Неадек- } \\
\text { ватне емоційне вибірко- } \\
\text { ве реагування }\end{array}$ & $2,40 \pm 3,63$ & $4,55 \pm 3,97$ & $16,00 \pm 1,73$ & $14,18 \pm 6,16$ & $<0,01$ & $<0,01$ & $<0,01$ & $<0,01$ & $<0,01$ & $>0,05$ \\
\hline $\begin{array}{l}\text { 2.2. Резистенція. Емоцій- } \\
\text { но-моральна дезорієнта- } \\
\text { ція }\end{array}$ & $8,02 \pm 4,63$ & $7,28 \pm 4,71$ & $5,00 \pm 0,00$ & $7,78 \pm 5,54$ & $>0,05$ & $>0,05$ & $>0,05$ & $>0,05$ & $>0,05$ & $>0,05$ \\
\hline $\begin{array}{l}\text { 2.3. Резистенція. Розши- } \\
\text { рення сфери економії } \\
\text { емоцій }\end{array}$ & $8,14 \pm 2,98$ & $\begin{array}{c}21,62 \pm 13,8 \\
1\end{array}$ & $12,67 \pm 4,04$ & $23,68 \pm 8,04$ & $<0,01$ & $<0,05$ & $<0,01$ & $>0,05$ & $>0,05$ & $<0,05$ \\
\hline $\begin{array}{l}\text { 2.4. Резистенція. Редук- } \\
\text { ція професійних обов'яз- } \\
\text { ків }\end{array}$ & $5,88 \pm 6,58$ & $6,98 \pm 6,86$ & $13,67 \pm 2,89$ & $15,18 \pm 1,57$ & $>0,05$ & $>0,05$ & $<0,01$ & $>0,05$ & $<0,01$ & $>0,05$ \\
\hline Резистенція & $24,44 \pm 9,02$ & $40,43 \pm 9,69$ & $47,33 \pm 4,51$ & $\begin{array}{c}60,80 \pm 10,3 \\
8\end{array}$ & $<0,01$ & $<0,01$ & $<0,01$ & $>0,05$ & $<0,01$ & $<0,05$ \\
\hline $\begin{array}{l}\text { 3.1. Виснаження. Емо- } \\
\text { ційний дефіцит }\end{array}$ & $4,05 \pm 3,44$ & $4,49 \pm 4,75$ & $11,33 \pm 9,29$ & $9,73 \pm 5,48$ & $>0,05$ & $<0,05$ & $<0,01$ & $>0,05$ & $<0,01$ & $>0,05$ \\
\hline $\begin{array}{l}\text { 3.2. Виснаження. Емо- } \\
\text { ційна відстороненість }\end{array}$ & $7,46 \pm 2,52$ & $10,21 \pm 3,45$ & $12,00 \pm 3,61$ & $14,48 \pm 2,95$ & $<0,01$ & $<0,05$ & $<0,01$ & $>0,05$ & $<0,01$ & $>0,05$ \\
\hline $\begin{array}{l}\text { 3.3. Виснаження. Особи- } \\
\text { стісна відстороненість } \\
\text { (деперсоналізація) }\end{array}$ & $3,53 \pm 3,06$ & $5,34 \pm 5,92$ & $8,67 \pm 9,81$ & $20,43 \pm 2,45$ & $>0,05$ & $>0,05$ & $<0,01$ & $>0,05$ & $<0,01$ & $<0,05$ \\
\hline $\begin{array}{l}\text { 3.4. Виснаження. Психо- } \\
\text { соматичні і психовегета- } \\
\text { тивні порушення) }\end{array}$ & $2,63 \pm 1,22$ & $3,49 \pm 3,83$ & $10,00 \pm 0,00$ & $20,13 \pm 4,54$ & $>0,05$ & $<0,01$ & $<0,01$ & $<0,05$ & $<0,01$ & $<0,01$ \\
\hline Виснаження & $17,67 \pm 4,33$ & $\begin{array}{c}23,53 \pm 13,4 \\
3\end{array}$ & $\begin{array}{l}42,00 \pm 20,4 \\
2\end{array}$ & $64,75 \pm 8,66$ & $<0,05$ & $<0,01$ & $<0,01$ & $>0,05$ & $<0,01$ & $>0,05$ \\
\hline Загальна сума & $52,39 \pm 9,57$ & $\begin{array}{c}82,04 \pm 24,0 \\
6 \\
\end{array}$ & $\begin{array}{c}145,00 \pm 22 \\
61\end{array}$ & $\begin{array}{c}201,28 \pm 18 \\
72\end{array}$ & $<0,01$ & $<0,01$ & $<0,01$ & $<0,01$ & $<0,01$ & $<0,01$ \\
\hline
\end{tabular}


Аналіз клінічного змісту виявлених симптомів та фаз СЕВ у обстежених дозволив встановити наступне.

У респондентів підгрупи Г1-0, 3 низьким рівнем дезадаптації, симптомів та фаз що формуються чи сформованих, не виявлено.

В підгрупі Г1-1, серед осіб з низьким рівнем дезадаптації та СЕВ, що формується, формування СЕВ відбувалося за фазою «Резистенція» 3 середнім показником

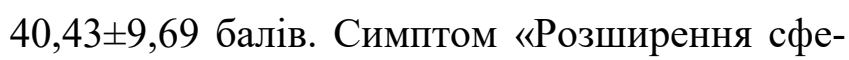
ри економії емоцій» в даній фазі був сформованим та домінуючим з середнім показником у $21,62 \pm 13,81$ балів, що дозволяє зробити припущення, що поява окремих ознак CEB передувала появі клінічно окреслених дезадаптивних проявів.

Слід відмітити формування в даній групі симптому «Емоційна відстороненість» 3 середнім показником10,21 $\pm 3,45$ балів у фазі «Виснаження», що проявлялось зниженням рівня емоційного реагування на травмуючі події чи обставини.

Респонденти даної групи відмічали втому від надмірної комунікації, пов'язаної із виконуваною діяльністю. Як форму захисту обирали зменшення контактів, однак більше не в сфері власної діяльності, а в спілкуванні з близькими, друзями, знайомими та зниження рівня емоційного реагування на негативні події чи обставини, а також зниження вдоволеності від виконуваної діяльності.

В підгрупі Г2-1 з наявними розладами дезадаптації та СЕВ, що формується, формування СЕВ відбувалося за фазою «Напруга» 3

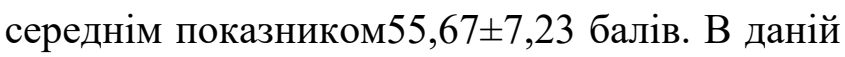
фазі, всі симптоми знаходились на стадії формування, та за рівнем середнього показника розмістились наступним чином: $15,33 \pm 2,526 а л і в$ - «Невдоволеність собою»,

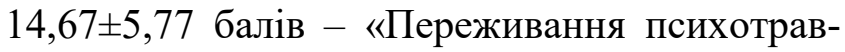
муючих обставин», $13,00 \pm 5,29$ балів -

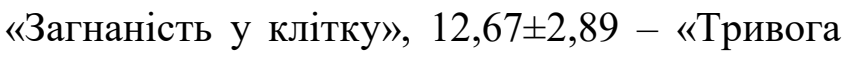
та депресія».

Слід відмітити також наявність сформованого симптому «Неадекватне вибіркове реагування» $(16,00 \pm 1,73$ балів) та симптомів що входять до фази «Резистенція» та «Виснаження» у стадії формування: «Редукція професійних обов'язків» $(13,67 \pm 2,89$ балів) та «Розширення сфери економії емо-

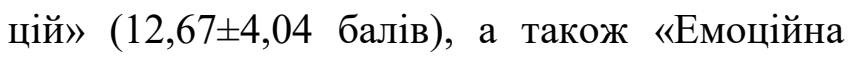
відстороненість» $(12,00 \pm 3,61$ балів) та «Психосоматичні i психовегетативні порушення» $(10,00 \pm 0,00$ балів), що свідчить про високий ризик формування СЕВ у респондентів даної групи та пов'язане з цим поглиблення явищ дезадаптації.

Респонденти даної групи в якості захисту від стресу зменшували власну активність у волонтерській діяльності, вказували на зменшення рівня спілкування з близькими, друзями, знайомими та зниження рівня емоційного реагування на негативні події чи обставини, а також на негативні переживання, пов'язані із виконуваною діяльністю аж до погіршення 
самопочуття.

В підгрупі Г2-2 найвищим був рівень «Напруги» (75,73 $\pm 8,36$ бали), наступним було «Виснаження» $(64,75 \pm 8,66$ балів) та «Резистенція» $(60,80 \pm 10,38$ балів).

Внаслідок дії захисних механізмів СЕВ у відповідь на психотравмуючий вплив виконуваної діяльності, відбувається скорочення емоційних витрат, наростання явищ тривоги та депресії, деперсоналізації та підвищення рівня психосоматичних та психовегетативних порушень.

У фазі «Напруги», домінуючими симптомами були «Переживання психотравмуючих обставин» $(23,23 \pm 6,29$ бали) та «Тривога і депресія» $(21,93 \pm 5,09$ бали). Сформованим був також симптом «Загнаність у кліт-

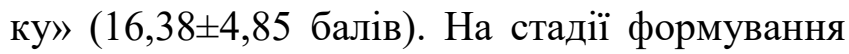
був симптом «Незадоволеність собою» $(14,20 \pm 2,94$ бали).

Вищезазначене було пов'язано в першу чергу із підвищеним фізичним та психологічним навантаженням, пов'язаним із виконуваною діяльністю та організаційними недоліками. Під тиском цих психотравмуючих обставин волонтери відмічали відчуття «загнаності в клітку» та безвиході. В результаті невдач чи неможливості впливу на психотравмуючі обставини респонденти вказували на невдоволення собою та виконуваною діяльністю, втрату спокою через роботу, тривожні очікування, сум та розчарування.

В фазі «Виснаження» домінуючими були симптоми «Особистісна відстороненість» $(20,43 \pm 2,45$ бали) та «Психосоматичні і психовегетативні порушення» $(20,13 \pm 4,54$ бали). Симптом «Емоційна відстороненість» перебував на стадії формування $(14,48 \pm 2,95$ балів). Респонденти відмічали накопичення втоми від людських проблем, розчарування від роботи з людьми, «невдячність» та зниження вдоволеності від виконуваної діяльності, та іiі значимості.

В структурі симптому «Психосоматичні і психовегетативні порушення» респонденти відмічали порушення засинання, через переживання, пов'язані з роботою, поганий настрій, підвищення тиску та неприємні відчуття в області серця, нездужання після робочого дня та погіршення самопочуття, пов'язане із роботою з людьми.

В фазі «Резистенція», домінуючим та найбільш вираженим в СЕВ був симптом «Розширення сфери економії емоцій» (23,68土8,04 балів). Симптом «Редукція професійних обов'язків» знаходився на стадії формування $(15,18 \pm 1,57$ бали). Опитувані відмічали високий рівень емоційного дефіциту в спілкуванні з близькими, друзями, знайомими та згортання активності виконуваної діяльносTi.

Аналіз особливостей дезадаптивних проявів у обстежених груп Г1 та Г2 виявив, що волонтерам притаманний виражений рівень дезадаптації: середній показник у групі Г2 склав $67,49 \pm 17,14$ балів. При такому рівні 
дезадаптації особа потребує обов'язкового втручання фахівця, зміни виду діяльності або проведення програми з реадаптації (Табл. 4). найбільшу вираженість мали емоційні порушення (середній показник 5,79 $\pm 2,08$ балів), порушення, що відносяться до особливостей

Таблиия 4.

Варіативність дезадаптивних проявів у обстежених основної групи (Г2) та групи порівняння (Г1) (середній бал)

\begin{tabular}{|l|c|c|c|c|}
\hline \multirow{2}{*}{ Фаза / Симптом } & \multicolumn{2}{|c|}{ Середнє значення, М \pm m (балів) } & \multirow{2}{*}{ р Г1/Г2 } \\
\cline { 2 - 4 } & $\Gamma 1$ & $\Gamma 2$ & Разом & \\
\hline Емоційні зсуви & $5,74 \pm 2,91$ & $9,88 \pm 2,14$ & $6,95 \pm 3,30$ & $<0,01$ \\
\hline Особливості окремих психічних процесів & $0,23 \pm 0,64$ & $3,28 \pm 2,06$ & $1,12 \pm 1,86$ & $<0,01$ \\
\hline Зниження загальної активності & $2,00 \pm 1,70$ & $6,77 \pm 2,11$ & $3,39 \pm 2,84$ & $<0,01$ \\
\hline Відчуття втоми & $2,64 \pm 2,19$ & $8,77 \pm 1,86$ & $4,44 \pm 3,49$ & $<0,01$ \\
\hline Соматовегетативні порушення & $0,57 \pm 1,18$ & $8,58 \pm 8,47$ & $2,91 \pm 5,92$ & $<0,01$ \\
\hline Порушення циклу сон-пильнування & $2,03 \pm 3,90$ & $12,72 \pm 2,68$ & $5,16 \pm 6,05$ & $<0,01$ \\
\hline Особливості соціальної взаємодії & $4,65 \pm 2,48$ & $10,84 \pm 3,37$ & $6,46 \pm 3,95$ & $<0,01$ \\
\hline Зниження мотивації до діяльності & $2,87 \pm 2,27$ & $6,65 \pm 1,17$ & $3,97 \pm 2,65$ & $<0,01$ \\
\hline Загальний показник & $20,73 \pm 5,00$ & $67,49 \pm 17,14$ & $34,41 \pm 23,62$ & $<0,01$ \\
\hline
\end{tabular}

Порівняння варіативності дезадаптивних провів залежно від рівня СЕВ (Табл.5, Рис.1) показало, що структура дезадаптивних проявів із наростанням явищ СЕВ змінювалася.

У Г1-0, серед осіб, з низьким рівнем дезадаптації та відсутніми ознаками $\mathrm{CEB}$, в структурі дезадаптивних проявів превалювали емоційні порушення (середній показник

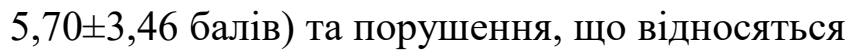
до особливостей соціальної взаємодії

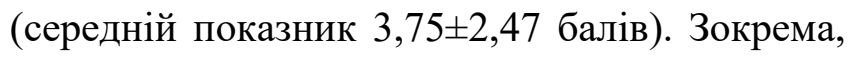
найчастіше опитувані відзначали зростання дратівливості, коливання настрою, сварки 3 рідними та колегами.

У Г1-1 з низькою ПД та CEB, що формується, в структурі дезадаптивних проявів соціальної взаємодії (середній показник $5,74 \pm 2,04$ балів ) та накопичення втоми

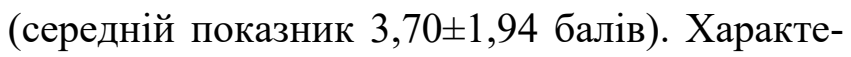
рним було зниження рівня мотивації (середній

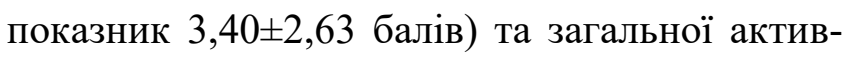

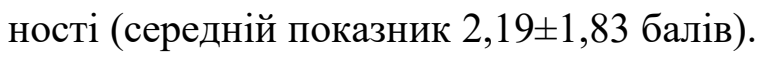

Серед респондентів Г2-1, 3 наявними дезадаптивними розладами та $\mathrm{CEB}$, що формується, спостерігалося значне підвищення усіх проявів дезадаптації. Відбулося значне підвищення рівня порушень в сфері соціальної взаємодії (середній показник 10,33 $\pm 3,79$ балів) та психофізіологічних розладів: емоційних порушень (середній показник 9,33 $\pm 2,31$ балів), порушень циклу сну (середній показник $8,33 \pm 1,53$ балів) та рівня втоми (середній показник $6,67 \pm 2,89$ балів). Значно знизився 


\section{Варіативність дезадаптивних проявів залежно від рівня СЕВ (середній бал)}

\begin{tabular}{|c|c|c|c|c|c|c|c|c|c|c|}
\hline \multirow[b]{2}{*}{ Показник } & \multicolumn{4}{|c|}{ Середнє значення, $\mathrm{M} \pm \mathrm{m}$ (балів) } & \multicolumn{6}{|c|}{ Розбіжності } \\
\hline & $\Gamma 1-0$ & $\Gamma 1-1$ & $\Gamma 2-1$ & $\Gamma 2-2$ & $\begin{array}{c}\mathrm{p} \Gamma 1- \\
0 / \Gamma 1- \\
1\end{array}$ & $\begin{array}{c}\mathrm{p} \Gamma 1- \\
0 / \Gamma 1- \\
2\end{array}$ & $\begin{array}{c}\mathrm{p} \Gamma 1- \\
0 / \Gamma 2- \\
2\end{array}$ & $\begin{array}{c}\mathrm{p} \text { Г1- } \\
1 / \Gamma 2- \\
1\end{array}$ & $\begin{array}{c}\mathrm{p} \Gamma 1- \\
1 / \Gamma 2- \\
2\end{array}$ & $\begin{array}{c}\mathrm{p} \Gamma 2- \\
1 / \Gamma 2- \\
2\end{array}$ \\
\hline Емоційні зсуви & $5,70 \pm 3,46$ & $5,79 \pm 2,08$ & $9,33 \pm 2,31$ & $9,93 \pm 2,15$ & $>0,05$ & $>0,05$ & $<0,01$ & $<0,05$ & $<0,01$ & $>0,05$ \\
\hline $\begin{array}{l}\text { Особливості окремих } \\
\text { психічних процесів }\end{array}$ & $0,35 \pm 0,77$ & $0,09 \pm 0,41$ & $2,00 \pm 0,00$ & $3,38 \pm 2,11$ & $>0,05$ & $<0,05$ & $<0,01$ & $<0,01$ & $<0,01$ & $>0,05$ \\
\hline $\begin{array}{l}\text { Зниження загальної } \\
\text { активності }\end{array}$ & $1,84 \pm 1,59$ & $2,19 \pm 1,83$ & $4,00 \pm 1,73$ & $6,98 \pm 2,01$ & $>0,05$ & $<0,05$ & $<0,01$ & $>0,05$ & $<0,01$ & $<0,05$ \\
\hline Відчуття втоми & $1,77 \pm 2,01$ & $3,70 \pm 1,94$ & $6,67 \pm 2,89$ & $8,93 \pm 1,72$ & $<0,01$ & $<0,01$ & $<0,01$ & $>0,05$ & $<0,01$ & $>0,05$ \\
\hline $\begin{array}{l}\text { Соматовегетативні пору- } \\
\text { шення }\end{array}$ & $0,37 \pm 0,94$ & $0,81 \pm 1,39$ & $1,33 \pm 1,53$ & $9,13 \pm 8,53$ & $>0,05$ & $>0,05$ & $<0,01$ & $>0,05$ & $<0,01$ & $<0,05$ \\
\hline $\begin{array}{l}\text { Порушення циклу сон- } \\
\text { пильнування }\end{array}$ & $2,81 \pm 4,96$ & $1,09 \pm 1,57$ & $8,33 \pm 1,53$ & $13,05 \pm 2,45$ & $>0,05$ & $>0,05$ & $<0,01$ & $<0,01$ & $<0,01$ & $<0,05$ \\
\hline $\begin{array}{l}\text { Особливості соціальної } \\
\text { взаємодії }\end{array}$ & $3,75 \pm 2,47$ & $5,74 \pm 2,04$ & $10,33 \pm 3,79$ & $10,88 \pm 3,39$ & $<0,01$ & $<0,05$ & $<0,01$ & $<0,05$ & $<0,01$ & $>0,05$ \\
\hline $\begin{array}{l}\text { Зниження мотивації до } \\
\text { діяльності }\end{array}$ & $2,42 \pm 1,84$ & $3,40 \pm 2,63$ & $5,67 \pm 2,08$ & $6,73 \pm 1,09$ & $<0,05$ & $<0,05$ & $<0,01$ & $>0,05$ & $<0,01$ & $>0,05$ \\
\hline Загальний показник & $19,02 \pm 5,25$ & $22,81 \pm 3,78$ & $47,67 \pm 8,08$ & $68,98 \pm 16,75$ & $<0,01$ & $<0,01$ & $<0,01$ & $<0,01$ & $<0,01$ & $<0,05$ \\
\hline
\end{tabular}

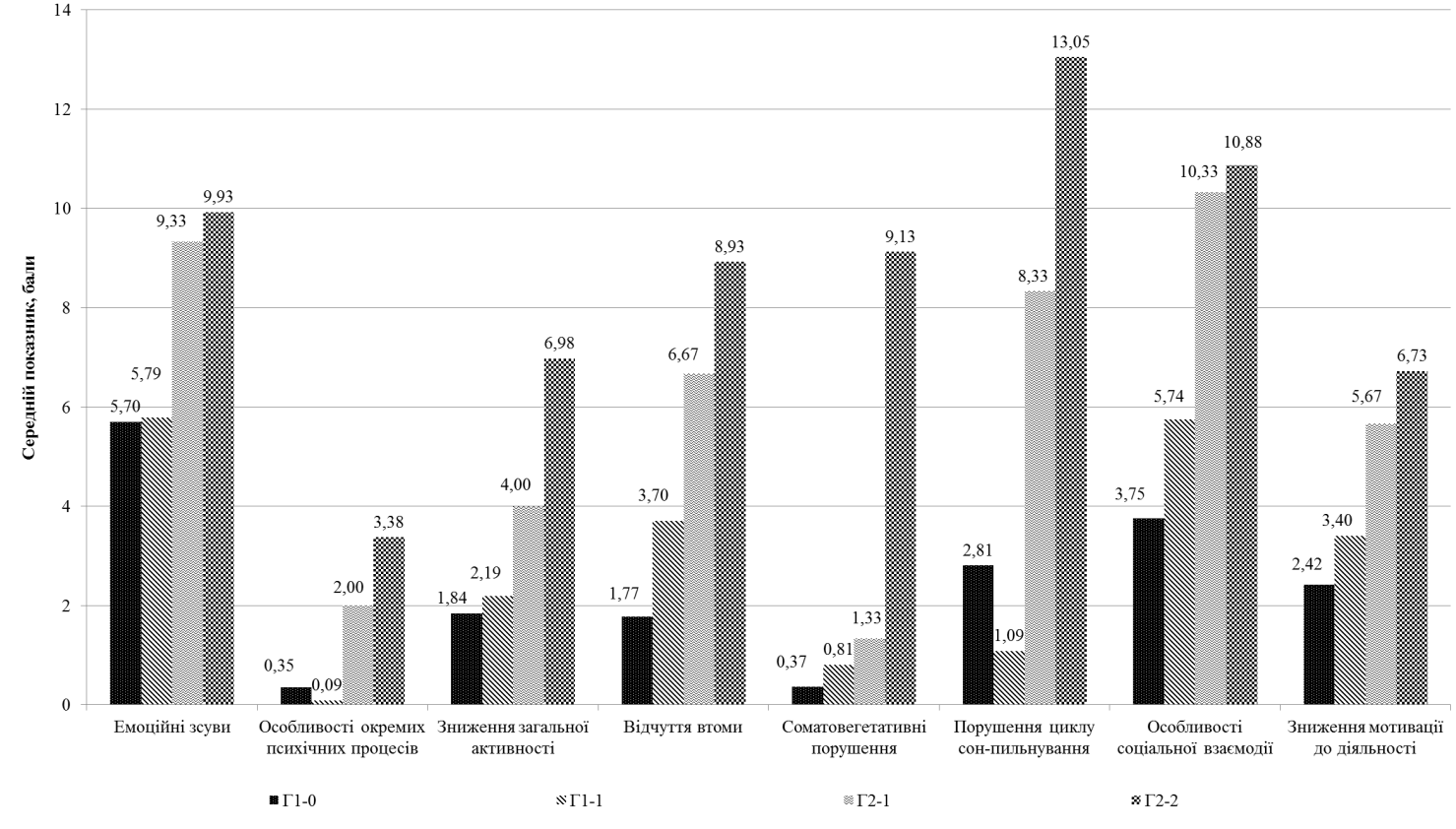

Рис. 1. Варіативність дезадаптивних проявів залежно від рівня СЕВ 
рівень мотивації до виконуваної діяльності (середній показник 5,67 $\pm 2,08$ балів).

В Г2-2, з наявними дезадаптивними розладами та сформованим CEB, найвищий рівень мали порушення циклу сну (середній показник $13,05 \pm 2,45$ балів) та особливості соціальної взаємодії (середній показник 10,88 $\pm 3,39$ балів), емоційні порушення (середній показник 9,93 $\pm 2,15$ балів), соматовегетативні порушення (середній показник 9,13 $\pm 8,53$ балів), відчуття втоми (середній показник 8,93 $\pm 1,72$ балів), зниження рівня загальної активності (середній показник $6,98 \pm 2,01$ балів) та мотивації до діяльності

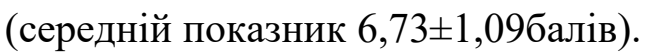

В структурі явищ дезадаптації з наростанням ознак СЕВ, відбулося зміщення від психо-емоційних порушень до порушень циклу сну, соматовегетативних та психосоціальних порушень, що свідчить про перехід реакцій з рівня емоцій на рівень психосоматики.

\section{Висновки.}

1. Волонтерська діяльність несе потенційні ризики розвитку СЕВ. У 61,2\% з загальної кількості обстежених осіб, встановлено наявність або окремих фаз СЕВ, що формуються (34,0\%), або сформованих (27,2\%).

2. Поява ознак СЕВ передує появі клінічно окреслених дезадаптивних проявів та впливає на їх структуру.

3. СЕВ, вмикаючи механізми захисту від стресу, підвищує прояви дезадаптації щодо волонтерської діяльності, що в сукупності негативно впливає на фізичне, психологічне та соціальне функціонування волонтерів.

3. Внаслідок дії захисних механізмів CEВ у відповідь на психотравмуючий вплив виконуваної діяльності, відбувається скорочення емоційних витрат, наростання явищ тривоги та депресії, деперсоналізації та підвищення рівня психосоматичних та психовегетативних порушень.

5. В структурі явищ дезадаптації 3 наростанням ознак СЕВ, відбувається зміщення від психо-емоційних порушень до порушень циклу сну, соматовегетативних та психосоціальних порушень, що свідчить про перехід реакцій з рівня емоцій на рівень психосоматики.

6. Результати дослідження особливостей СЕВ та його ролі в структурі дезадаптації волонтерів можуть бути використані при прийнятті організаційних рішень по профілактиці СЕВ, розвитку медико-психологічної складової волонтерської діяльності, а також в програмах добору волонтерів.

\section{Перспектива подальших досліджень} полягає в розробці заходів психологічної корекції та психопрофілактичної підтримки волонтерів, діяльність яких пов'язана з забезпеченням військових в зоні АТО, що буде зроблено нами з урахуванням визначених маркерів-мішеней, однією з яких є СЕВ. 


\section{Перелік використаних джерел:}

1. Сидоренко О. О. Волонтерський рух у світі та в Україні [Електронний ресурс] / О.О.Сидоренко // Актуальні проблеми психології. - 2016. - Том 10, Вип. 28 - Режим доступу: http://www.appsychology.org.ua/index.php/ua/ arkhiv-vydannia/tom-10/vipusk-28-v-10-mua.

2. Забота о волонтерах. Методы оказания психосоциальной помощи. Справочный центр психосоциальной поддержки Международная Федерация обществ Красного Креста и Красного полумесяца. Режим доступу:http://pscentre.org/wp-content/uploads/

volunteers_RU.pdf

3. Лидер группы «Антитела» рассказал о причинах «выгорания» военного волонтерства в Украине. Режим доступу: http://zn.ua/UKRAINE/lider-gruppy-antitelarasskazal-o-prichinah-vygoraniya-voennogo-volonterstva-v -ukraine-216738_html

4. Чому вмирають волонтери. Режим доступу: http:// uzv.org.ua/chomu-vmirayut-volonteri/.

5. Світовий рейтинг благодійності World giving index 2015 Режим доступу: https://www.cafonline.org/about-us/ publications/2015-publications/world-giving-index-2015

6. Волонтери втомилися. Режим доступу:http:/gkpress.if.ua/volontery-vtomylysya/

7. Волонтер: Простите, я больше не буду помогать в АТО. Это моё решение, за которое, мне не стыдно. Режим доступу: http://antikor.com.ua/articles/134138prostite_ja_boljshe_ne_budu_pomogatj_v_ato._eto_moe_re shenie_za_kotoroe_mne_ne_stydno.

8. Добровольиі і волонтери. Чи допомагають армії на третій рік війни. Режим доступу: http://espreso.tv/ article/2016 /06/10/ dobrovolci_i_volontery _chy_lyshyvsya_entuziazm_na_tretiy_rik_viyny.

9. Волонтерство: небезпечна втома. Режим доступу: http://sp.lvivport.com/lvivnews/n/31063.

10. Згасання волонтерського «буму»: байдужість, зубожіння та розчарування українців Соломія ГОЛОВІНА, Львівський портал. Режим доступу: http:// portal.lviv.ua/news/2016/11/04/zgasannya-volonterskogo- bumu-bayduzhist-zubozhinnya-ta-rozcharuvannyaukrayintsiv

11. Волонтеры о сотнях спасенных жизней, концерте под минами и о возвращении в 2014-й. Режим доступу: http://www.depo.ua/rus/war/volonteri-pro-sotnivryatovanih-zhittiv-pisnyu-pid-gradami--05122016203000. 12. Українські волонтери: втома від війни і друге дихання. Режим доступу: http://socportal.info/2016/08/17/ ukrayins-ki-volonteri-vtoma-vid-vijni-i-drugedihannya.html.

13. Як змінилося життя прикарпатців, які за покликом серця допомагають воїнам в АТО. Режим доступу: http://www.blitz.if.ua/news/yak-zminylosya-zhyttyaprykarpatciv-yaki-za-poklykom-sercya-dopomagayutvoinam-v-ato.html

14. Волонтер Леся Литвинова: «Не верьте сильным людям, когда они говорят, что у них все в порядке». Режим доступу:http://ukrainianwall.com/blogosfera/ volonter-lesya-litvinova-ne-verte-silnym-lyudyam-kogdaoni-govoryat-chto-u-nix-vse-v-poryadke/

15. Кто поможет волонтерам вернуться с войны. Режим доступу: http://bigkiev.com.ua/content/kto-pomozhetvolonteram-vernutsya-s-voyny

16. Лексиконь психиатрии Всемирной Организации Здравоохранения: Лексикон психиатрических и относящихся к психическому здоровью терминов (2-е изд.). Лексикон терминов, относящихся к алкоголю и другим психоактивным средствам. Лексикон кросскультуральных терминов, относящихся к психическому здоровью / Пер. с англ. под общ. ред. В. Б. Позняка. К.: Сфера, 2001. - 398 c.

17. World Health Organization. The ICD-10 Classification of Mental and Behavioral Disorders: clinical descriptions and diagnostic guidelines. - Geneva: WHO, 1992.

18. Грииук О. В. Основні принципи та підходи в дослідженні синдрому емоційного вигорання у зарубіжній психології / О. В. Грицук // Актуальні проблеми психології. - 2012. - Т. 1, Вип. 35. - С. 30-33. - Режим доступу: http://nbuv.gov.ua/UJRN/appsuh_2012_1_35_8

19. Мащцак С. О. Професійне вигорання особистості як 
соціально-психологічна проблема / С. О. Мащак // Науковий вісник Львівського державного університету внутрішніх справ. серія психологічна. - 2012. Вип. 2(1). - С. 444 - 452. Режим доступу: http:// nbuv.gov.ua/UJRN/Nvldu_2012_2(1)_54

20. Салогуб $A$. М. Структура и содержание синдрома эмоционального выгорания в исследованиях зарубежных и отечественных ученых / А. М. Салогуб // Молодой ученый. — 2014. — №5. - C. 459-461.

21. Kaschka W. P., Korczak D, Broich K. Burnout: a Fashionable Diagnosis. Deutsches Ärzteblatt International. 2011; 108(46):781-787. doi:10.3238/arzteb1.2011.0781. The role of psychosocial working conditions on burnout and its core component emotional exhaustion - a systematic review

22. Seidler A., Thinschmidt, M., Deckert, S., Then, F., Hegewald, J., Nieuwenhuijsen, K., ... \& Oberbauer, R. (2014). Publisher main menu. Journal of Occupational Medicine and Toxicology, 9, 10.

23. Практикум по психологии менеджмента и профессиональной деятельности: Учеб. пособие / Подред. Г. С. Никифорова, М. А. Дмитриевой, В. М. Снеткова // СПб.: Изд-во С.-Петерб. ун-та, 2003. - С.147 - 151.

24. Водопьянова Н. Е. Психодиагностика стресса / Н. Е. Водопьянова// Питер; СПб.; 2009. С. 126.

\section{References (Transliteration):}

1. Sydorenko $O$. O. Volonters'kyy rukh u sviti ta $\mathrm{v}$ Ukrayini [Elektronnyy resurs] / O. O. Sydorenko // Aktual'ni problemy psykholohiyi. - 2016. - Tom 10, Vyp. 28 Rezhym dostupu: http://www.appsychology.org.ua/ index.php/ua/arkhiv-vydannia/tom-10/vipusk-28-v-10-mua. 2. Zabota o volonterakh. Metody okazanyya psykhosotsyal'noy pomoshchy. Spravochnыy tsentr psykhosotsyal'noy podderzhky Mezhdunarodnaya Federatsyya obshchestv Krasnoho Kresta y Krasnoho polumesyatsa. Rezhym dostupu: http://pscentre.org/wpcontent/uploads/volunteers_RU.pdf

3. Lyder hruppi «Antytela» rasskazal o prychynakh «vuhoranyya» voennoho volonterstva v Ukrayne. Rezhym dostupu: http://zn.ua/UKRAINE/lider-gruppy-antitelarasskazal-o-prichinah-vygoraniya-voennogo-volonterstva-v -ukraine-216738_html

4. Chomu vmyrayut' volontery. Rezhym dostupu: http:// uzv.org.ua/chomu-vmirayut-volonteri/

5. Svitovyy reytynh blahodiynosti World giving index 2015 Rezhym dostupu: https://www.cafonline.org/about-us/ publications/2015-publications/world-giving-index-2015

6. Volontery vtomylysya. Rezhym dostupu: http://gkpress.if.ua/volontery-vtomylysya/

7. Volonter: Prostyte, ya bol'she ne budu pomohat' v ATO. Eto moë reshenye, za kotoroe, mne ne stыdno. Rezhym dostupu: http://antikor.com.ua/articles/134138prostite_ja_boljshe_ne_budu_pomogatj_v_ato._eto_moe_re shenie_za_kotoroe_mne_ne_stydno

8. Dobrovol'tsi i volontery. Chy dopomahayut' armiyi na tretiy rik viyny. Rezhym dostupu: http://espreso.tv/ article/2016/06/10/dobrovolci_i_volontery_chy_lyshyvsya _entuziazm_na_tretiy_rik_viyny

9. Volonterstvo: nebezpechna vtoma. Rezhym dostupu: http://sp.lvivport.com/lvivnews/n/31063.

10. Zhasannya volonters'koho «bumu»: bayduzhist', zubozhinnya ta rozcharuvannya ukrayintsiv Solomiya HOLOVINA, L'vivs'kyy portal. Rezhym dostupu: http:// portal.lviv.ua/news/2016/11/04/zgasannya-volonterskogobumu-bayduzhist-zubozhinnya-ta-rozcharuvannyaukrayintsiv.

11. Volontery o sotnyakh spasennykh zhyzney, kontserte pod mynamy y o vozvrashchenyy v 2014-y. Rezhym dostupu: http://www.depo.ua/rus/war/volonteri-pro-sotnivryatovanih-zhittiv-pisnyu-pid-gradami--05122016203000

12. Ukrayins'ki volontery: vtoma vid viyny i druhe dykhannya. Rezhym dostupu: http:// socportal.info/2016/08/17/ukrayins-ki-volonteri-vtoma-vidvijni-i-druge-dihannya.html

13. Yak zminylosya zhyttya prykarpattsiv, yaki za poklykom sertsya dopomahayut voyinam v ATO. Rezhym dostupu: http://www.blitz.if.ua/news/yak-zminylosyazhyttya-prykarpatciv-yaki-za-poklykom-sercya- 
dopomagayut-voinam-v-ato.html.

14. Volonter Lesya Lytvynova: «Ne ver'te syl'num lyudyam, kohda ony hovoryat, chto $\mathrm{u}$ nykh vse $\mathrm{v}$ poryadke». Rezhym dostupu: http://ukrainianwall.com/ blogosfera/volonter-lesya-litvinova-ne-verte-silnymlyudyam-kogda-oni-govoryat-chto-u-nix-vse-v-poryadke/. 15. Kto pomozhet volonteram vernut'sya s voynu. Rezhym dostupu: http://bigkiev.com.ua/content/kto-pomozhetvolonteram-vernutsya-s-voyny.

16. Leksykonu psykhyatryy Vsemyrnoy Orhanyzatsyy Zdravookhranenyya: Leksykon psykhyatrycheskykh y otnosyashchykhsya k psykhycheskomu zdorov'yu termynov (2-e yzd.). Leksykon termynov, otnosyashchykhsya $\mathrm{k}$ alkoholyu y druhym psykhoaktyvnыm sredstvam. Leksykon kross-kul'tural'nukh termynov, otnosyashchykhsya k psykhycheskomu zdorov'yu / Per. s anhl. pod obshch. red. V. B. Poznyaka. - K.: Sfera, 2001. - $398 \mathrm{~s}$.

17. World Health Organization. The ICD-10 Classification of Mental and Behavioral Disorders: clinical descriptions and diagnostic guidelines. - Geneva: WHO, 1992.

18. Hrytsuk $O$. $V$. Osnovni pryntsypy ta pidkhody $\mathrm{v}$ doslidzhenni syndromu emotsiynoho vyhorannya $u$ zarubizhniy psykholohiyi / O. V. Hrytsuk // Aktual'ni problemy psykholohiyi. - 2012. - T. 1, Vyp. 35. - S. 3033. - Rezhym dostupu: http://nbuv.gov.ua/UJRN/ appsuh_2012_1_35_8

19. Mashchak S. O. Profesiyne vyhorannya osobystosti yak sotsial'no-psykholohichna problema / S. O. Mashchak // Naukovyy visnyk L'vivs'koho derzhavnoho universytetu vnutrishnikh sprav. seriya psykholohichna. - 2012. - Vyp. 2 (1). - S. 444-452. - Rezhym dostupu: http://nbuv.gov.ua/ UJRN/Nvldu_2012_2(1)_54

20. Salohub A. M. Struktura y soderzhanye syndroma emotsyonal'noho vuhoranyya v yssledovanyyakh zarubezhnыkh y otechestvennukh uchenukh // Molodoy uchenыy. 2014. — \#5. - S. 459-461.

21. Kaschka W. P., Korczak D., Broich K. Burnout: a Fashionable Diagnosis. Deutsches Ärzteblatt International. 2011;108(46):781-787. doi:10.3238/arztebl.2011.0781. The role of psychosocial working conditions on burnout and its core component emotional exhaustion - a systematic review

22. Seidler A., Thinschmidt, M., Deckert, S., Then, F., Hegewald, J., Nieuwenhuijsen, K., ... \& Oberbauer, R. (2014). Publisher main menu. Journal of Occupational Medicine and Toxicology, 9, 10.

23. Praktykum po psykholohyy menedzhmenta y professyonal'noy deyatel'nosty: Ucheb. posobye / Pod red. H. S. Nykyforova, M. A. Dmytryevoy, V. M. Snetkova. SPb.: Yzd-vo S.-Peterb. un-ta, 2003. - S.147 - 151.

24. Vodop'yanova N. E. Psykhodyahnostyka stressa: Pyter; SPb.; 2009. S. 126.

\section{Markova Marianna}

Doctor of Medical Sciences, Professor, Professor of the Department of Sexology, Medical Psychology, Medical and Psychological Rehabilitation of the Kharkiv Medical Academy of Postgraduate Education, Kharkiv (Ukraine)

\section{Glagolych Slava}

Psychologist of Transcarpathian Regional Hospital for addictive patients, Uzhhorod (Ukraine)

\section{FEATURES OF EMOTIONAL BURNOUT AND ITS ROLE IN THE STRUCTURE OF MALADAPTATION OF VOLUNTEERS, WHOSE ACTIVITIES ARE RELATED TO THE PROVISION OF MILITARY PERSONNEL IN THE ATO ZONE}

\section{ABSTRACT}

In the article, the features of emotional burnout and psychological maladaptation of volunteers are analyzed.

The purpose of the work was to study the features of emotional burnout and psychological maladaptation of Ukrainian volunteers.

Using the questionnaire "Assessment of professional maladaptation" by O. N. Rodin in the version of M. A. Dmytriev and the methodol- 
ogy "Diagnostics of the level of "emotional burnout" by V. V. Boyko, it was examined 147 volunteers, whose activities were related to the provision of military personnel in the ATO zone for at least 1 year.

It is established that $29.3 \%$ of volunteers have phenomena or signs of maladaptation, while in $61.2 \%$, there are certain phases of the emotional burnout syndrome $(34.0 \%$ - those that are being formed, $27.2 \%$ - formed). In volunteers with signs of maladaptation, it was revealed significant symptoms of emotional burnout in almost all factors and symptoms. At the same time, the indicators of the experience of psycho-traumatic circumstances, the feeling of "being trapped in a cage", anxiety and depression, expansion of the sphere of saving of emotions, depersonalization, psychosomatic and psycho-vegetative disorders correspond to the formed symptoms; and indicators of dissatisfaction with oneself, inadequate emotional selective response, reduction of professional duties, emotional detachment and emotional deficiency correspond to the level the symptom that is being formed. The differentiation of the examined people into groups depending on the intensity of the emotional burnout syndrome and the level of maladaptation allowed to establish that in the volunteers with the low level of maladaptation and the symptoms of the emotional burnout, which was being formed, the burnout was in the phase of "Resistibility" with the dominance of the symptoms of the expansion of the sphere of emotional saving. In the volunteers with existing disorders of maladaptation and emotional burnout, which was being formed, this formation took place in the phase "Intenseness", and in the volunteers with existing maladaptation phenomena and the formed phases of burnout, it was mainly in the phase of "Intenseness" with high rates for all phases.

This is established that the structure of maladaptive manifestations with an increase in the phenomena of emotional burnout has been changed: in the initial phases, phenomena of emotional disorders, social dysfunction and asthenia dominated, with time the phenomena of insomnia with diminished motivation, which in the terminal phases were accompanied by a decrease in activity, dominated.

The obtained data allow us to conclude that there are signs of emotional burnout and psychological maladaptation, as well as their mutual connection in people whose activities are connected with volunteering.

Key words: volunteers, ATO, maladaptation, emotional burnout.

\section{Маркова Марианна Владиславовна}

Доктор медицинских наук, профессор, профессор кафедры сексологии, медицинской психологии, медицинской и психологической реабилитации Харьковской медицинской академии последипломного образования, Харьков (Украина)

\section{Глаголич Слава Юрьевна}

Психолог Закарпатского областного наркологического диспансера, Ужгород (Украина)

(C) Маркова М. В., Глаголич С. Ю. 
ОСОБЕННОСТИ ЭМОЦИОНАЛЬНОГО ВЫГОРАНИЯ И ЕГО РОЛЬ В СТРУКТУРЕ ДЕЗАДАПТАЦИИ ВОЛОНТЕРОВ, ДЕЯТЕЛЬНОСТЬ КОТОРЫХ СВЯЗАНА С ОБЕСПЕЧЕНИЯ ВОЕННЫХ В ЗОНЕ АТО

Аннотация. В статье проанализированы особенности эмоционального выгорания и психологической дезадаптации лиц, занимающихся волонтерской деятельностью.

Целью работы было изучение особенностей эмоционального выгорания и психологической дезадаптации украинских волонтеров.

С использованием опросника «Оценка профессиональной дезадаптации (ПД)» А. Н. Родиной в адаптации М. А. Дмитриевой и методики «Диагностика уровня «эмоционального выгорания»»» В. В. Бойко обследовано 147 человек, занимавшихся волонтерской деятельностью, связанной с обеспечением военных в зоне АTO, не менее 1 года.

Установлено, что у 29,3\% волонтеров имеются явления или признаки дезадаптации, при этом у 61,2\% выявлено признаков синдрома эмоционального выгорания (у 34,0\% формирующиеся, у 27,2\% - сформированные фазы синдрома). У волонтеров с признаками дезадаптации выявлена выраженная симптоматика эмоционального выгорания практически по всем факторам и симптомам; при этом показатели переживания психотравмирующих обстоятельств, ощущение «загнанности в клетку», тревоги и депрессии, расширение сферы экономии эмоций, деперсонализации, психосоматических и психовегетативных нарушений соответствуют сложившимся симптомам, а показатели неудовлетворенности собой, неадекватного эмоционального выборочного реагирования, редукции профессиональных обязанностей, эмоциональной отстраненности и эмоционального дефицита формирующейся симптоматике. Дифференциация обследованных на группы в зависимости от выраженности синдрома эмоционального выгорания и уровня дезадаптации позволила установить, что у волонтеров с низким уровнем дезадаптации и формирующейся симптоматикой эмоционального выгорания, происходило по фазе «резистенции» с доминированием расширения сферы экономии эмоций. У волонтеров с выраженной дезадаптацией и формирующимися симптомами эмоционального выгорания такое формирование происходило по фазе «напряжение», а у волонтеров с выраженной дезадаптацией и сформированными фазами выгорания - преимущественно по фазе «напряжения» с высокими показателям по всем фазам.

Установлено, что структура дезадаптивных проявлений с нарастанием явлений эмоционального выгорания менялась: при начальных фазах доминируют явления эмоциональных нарушений, социальной дисфункции и астении, в дальнейшем присоединяются явления диссомнии, сниженной мотивации, 
которые в динамике сопровождаются снижением активности.

Полученные данные позволяют сделать вывод о наличии признаков эмоционального выгорания и психологической дезадаптации, а также их взаимосвязи у лиц, занимающихся волонтерской деятельностью.

Ключевые слова: волонтеры, АТО, дезадаптация, эмоциональное выгорание. 